\title{
Evaluation of mechanical properties of grouts substituting the natural coarse aggregate for ceramic civil construction waste
}

\section{Avaliação das propriedades mecânicas de grautes contendo substituição do agregado graúdo natural por resíduos cerâmicos de construção civil}

\author{
Hinoel Zamis Ehrenbring ${ }^{1}$, Maira Janaina Ott ${ }^{1}$, Bianca Carlin Cadore ${ }^{1}$
} Diego Logue do Espirito Santo ${ }^{1}$, Bernardo Fonseca Tutikian ${ }^{1}$

\footnotetext{
${ }^{1}$ Universidade do Vale do Rio dos Sinos, Avenida Unisinos, 350, Cristo Rei, São Leopoldo, RS, Brasil. e-mail: bftutikian@unisinos.br, hzamis@unisinos.br,mairajo@unisinos.br, desanto@unisinos.br, biancadore96@gmail.com
}

\begin{abstract}
The lack of control regarding waste generation is a problem still faced by the construction industry, whereas its inputs could be used in the production of new cementitious composites, maintaining the quality, performance and sustainability of structures. This study developed grouts through the substitution of natural aggregate for residues of crushed ceramic bricks, evaluating its fresh state and mechanical properties. The samples displayed loss of workability and initial slump in fresh state, besides loss of compressive strength, elastic modulus, total water absorption and capillary water absorption in hardened state. In addition, composites with grog presented less consistency in fresh state when compared to the reference sample. The differences were even greater over time. As for the hardened state, the compressive strength of the samples was similar among them at both ages, and all results remained above $14 \mathrm{MPa}$ at 28 days, as required by ASTM C476, hence being characterized as structural grouts for masonry. For the elastic modulus test, the results were higher for samples with lower amounts of waste due to less internal voids and higher volume of natural aggregates. The substitution of natural aggregate for civil construction waste $(\mathrm{CCW})$ in the mixtures increased void ratio and water absorption, while causing the lowest specific gravities of the research. Overall, the sample that presented the most satisfactory values was CCW 25\%, showing that it is possible to obtain benefits from waste produced in factories and buildings, even for higher replacement levels, occasionally.
\end{abstract}

Keywords: ceramic waste; grouts; mechanical properties; physical properties; durability.

\section{RESUMO}

A falta de controle com relação à geração de resíduos é um problema ainda enfrentado pela indústria da construção civil, enquanto seus coprodutos podem reutilizados na produção de novos compósitos cimentícios, mantendo a qualidade, o desempenho e a sustentabilidade das estruturas. Este estudo desenvolveu grautes estruturais com substituição do agregado natural por resíduos de blocos cerâmicos triturados, avaliando seu estado fresco e propriedades mecânicas. Os ensaios realizados nas amostras foram a perda de abatimento ao longo do tempo no estado fresco e resistência à compressão, módulo de elasticidade, absorção total de água e absorção de água por capilaridade no estado endurecido. Além disso, compósitos contendo os resíduos cerâmicos apresentaram menor consistência no estado fresco quando comparados a amostra de referência (sem resíduo). As diferenças entre o abatimento inicial e final das misturas com resíduo foram aumentando ao longo do tempo. Quanto ao estado endurecido, a resistência à compressão das amostras foi semelhante entre elas em duas idades, e todos os resultados permaneceram acima de $14 \mathrm{MPa}$ aos 28 dias, conforme exigido pelo ASTM C476, sendo assim caracterizados como grautes estruturais para alvenaria portante. Para o teste do 
módulo de elasticidade, os resultados foram maiores para amostras com menor quantidade de resíduos devido ao menor número de vazios internos e maior volume de agregados naturais. A substituição do agregado natural por resíduos de construção civil (CCW) nas misturas aumentou o índice de vazios e a absorção de água, causando as menores densidades específicas da pesquisa. No geral, a amostra que apresentou os valores mais satisfatórios foi CCW 25\%, mostrando que é possível produzir grautes estruturais com resíduos cerâmicos de construção para utilização no setor, mesmo para níveis mais altos de reposição, ocasionalmente.

Palavras-chave: resíduos cerâmicos; grautes; propriedades mecânicas; propriedades físicas; durabilidade.

\section{INTRODUCTION}

Civil construction industry is known for being one of the greatest consumers of natural resources and generators of solid waste, and how does it expose Santos et al. [1], considering a disposal of materials between 20 to $50 \%$ of the total acquired. Most of these materials are not disposed correctly, namely without focusing on recycling and sustainability, regardless of the intensity of environmental regulations. Organizations, academic institutions, companies and other entities, along with the society, seek to develop more and more sustainable construction processes ([2] and [3]).

John and Agopyan [4] states that the civil construction production process can be divided in 5 stages: extraction of raw materials, production of materials, construction, use, and demolition, each producing environmental impact of some level. According to a Brazilian association [5], 45 million tons of civil construction waste were generated in Brazil in 2015, configuring an increase of $1.2 \%$ in comparison with the previous year. Seemingly, researches have been approaching higher rates of resources reuse, such as bricks and cement, as they are responsible for most of the carbon dioxide emission to the atmosphere, according Schackow et al. [6] and Bosque et al. [7].

Tüfekçi and Çakir [8] points out that recycling of the waste materials generated during construction and demolition activities is an advantageous way of conserving of the natural environment and maintaining stable sustainable development and generating a more economical mixture. Regarding exclusively red ceramic waste, Cabral et al. [9] noted that the leftovers of roof tiles, blocks and bricks accounted for nearly $30 \%$ of the total of solid waste generated in Brazilian cities. In grouts, this material shows good results in researches, depicting the potential of the material inherent to these cementitious matrices for González et al. [10].

In agreement with Omary et al. [11] and considering the importance of the civil construction production process, it is clear that it is not possible to attain sustainable development without making this industry sustainable. Therefore, ceramic waste $(\mathrm{CW})$, or ceramic grog, that is disposed during production in factories and use in buildings has been coming up as a topic that is promising for environmental impacts, mechanical performance and contributing directly to a better construction site management. Since extracting raw materials for manufacturing ceramic products causes changes to the environment, finding a new use for ceramic grogs is a way to minimize the problems caused, while still contributing to the reduction of the use of natural raw materials such as fine and coarse aggregate.

One of the possible uses for this waste is as aggregate for producing structural grouts. For Martins [12], grout results from a mixture of binding aggregate materials and water, with or without chemical admixtures, in proportions that grant fluidity without segregating the materials. Khalaf [13] and Suzuki et al. [14] showed that replacing granitic aggregate by recycled aggregate yields losses to compressive strength. This loss can be 10 to $35 \%$ for coarse aggregates and 30 to $40 \%$ for fine-grained aggregates. Concerning durability, concrete imbued with ceramic grog yields good durability, although with restrictions towards its application to reinforced concrete structures, according to Adamson et al. [15].

According to ABNT NBR 12118 [16], grout is an element whose purpose is to fill spaces in blocks and channels, allowing the unity of the system's reinforcement, increasing the structural system load-bearing capacity. Gouveia [17] stresses that some of the main properties presented by grouts are high initial strength, high fluidity, low permeability and high substrate adherence in hardened state. As explains Omary et al. [11], the mechanical properties in the hardened state of grout containing recycled aggregates depend on factors such as the type, quality and rate of recycled aggregate, mortar content and water to cement ratio (w/c). As mentioned by Wada [18], the addition of ceramic waste to cementitious matrices is limited to specific cases, because ceramic materials present high porosity, high absorption index. So, this material affects the slump and hydration of the matrices. Low mechanical strength and lamellar-shaped particles, all of which contribute to smaller mechanical strength, therefore, according to John and Agopyan [4], being indicated for use in grouts and low-strength components, for example, paving and mortar.

Conforming to the criteria of the Brazilian standard, ABNT NBR 15961-2 [19], the typical compres- 
sive strength of hardened state structural grout must be of at least $15 \mathrm{MPa}$ at 28 days and must correspond to double the block's compressive strength. As mentioned by Hamid et al. [20], the use of these recycled aggregates in grouts can be viable for that reason, since normative requirements are not so harsh as to propose high strength values. For Werle [21], some of the noteworthy advantages of the recycled aggregate are rougher texture and greater angularity, which help improving adherence between paste-aggregate and reduced the interfacial transition zone. So, despite the high presence of pores being characteristic, which consequently lowers elastic modulus, the interfacial zone between ceramic aggregate and cementitious paste ends up gaining more improvements as these materials gather up in comparison with the zone formed with basalt-type aggregates.

Seeking a use for this type of waste, this article developed a grout with substitution in mass with volume compensation of $0,25,50$ and $75 \%$ of the natural coarse aggregate for ceramic grog, analyzing its behavior in the fresh state behavior and mechanical properties affected by the substitution, though tests foreseen by standards.

\section{MATERIALS AND METHODS}

In this study, four mixtures were produced with distinct ratios of the ceramic grog in substitution of natural coarse aggregate (mass with volume compensation), considering the amounts of 0, 25, 50 and 75\%, as Table 1 shows.

Table 1: Proportion of the materials used in each mixture

\begin{tabular}{c|c|c|c|c|c|c}
\hline \multirow{2}{*}{ GROUT } & \multicolumn{5}{|c|}{ MIXTURE $\left(\mathbf{k g} / \mathbf{m}^{3}\right)$} & HRWR \\
\cline { 2 - 7 } & $\mathbf{c}$ & $\mathbf{s}$ & $\mathbf{g}$ & $\mathbf{C C W}$ & $\mathbf{w}$ & $\mathbf{( \% )}$ \\
\hline Reference (REF) & 375 & 825 & 636 & 0 & 229 & 0 \\
\hline CCW 25\% & 375 & 825 & 478 & 159 & 229 & 0.31 \\
\hline CCW 50\% & 375 & 825 & 319 & 319 & 229 & 0.83 \\
\hline CCW 75\% & 375 & 825 & 159 & 478 & 229 & 2.83 \\
\hline
\end{tabular}

*c: cement; s: sand; g: gravel; CCW: civil construction waste; w: water; REF: reference; HRWR: High-range Waterreducer.

The grogs were crafted by crushing structural ceramic bricks with compressive strength of $7 \mathrm{MPa}$. The consistency test was performed for the fresh state analysis, whose purpose was to determine slump loss during 120 minutes. Regarding the hardened state analysis, cylindrical specimens were molded for each mixture and age, which were subjected to the tests of compressive strength and elastic modulus at 28 days. Besides, total water absorption and capillary water absorption were determined at 28 days.

\subsection{Materials}

This study used Portland cement type high early (HE), as per classification of ASTM C150 [22]. The granulometric curve of cement grains was determined in accordance with ASTM C150 [22]. The cement had specific gravity of $2.69 \mathrm{~g} / \mathrm{cm}^{3}$ and its chemical analysis yielded the elements shown in Table 2 .

Table 2: Analysis of cement chemical composition

\begin{tabular}{c|c|c|c}
\hline $\begin{array}{c}\text { CHEMICAL } \\
\text { COMPOUND }\end{array}$ & $\begin{array}{c}\text { PERCENTAGE } \\
(\boldsymbol{\%})\end{array}$ & $\begin{array}{c}\text { CHEMICAL } \\
\text { COMPOUND }\end{array}$ & $\begin{array}{c}\text { PERCENTAGE } \\
(\boldsymbol{\%})\end{array}$ \\
\hline $\mathrm{Na}_{2} \mathrm{O}$ & 0.021 & $\mathrm{TiO}_{2}$ & 0.895 \\
\hline $\mathrm{MgO}$ & 3.871 & $\mathrm{Cr}_{2} \mathrm{O}_{3}$ & 0.018 \\
\hline $\mathrm{Al}_{2} \mathrm{O}_{3}$ & 13.624 & $\mathrm{MnO}$ & 0.071 \\
\hline $\mathrm{SiO}_{2}$ & 28.035 & $\mathrm{Fe}_{2} \mathrm{O}_{3}$ & 3.824 \\
\hline $\mathrm{P}_{2} \mathrm{O}_{5}$ & 0.052 & $\mathrm{ZnO}$ & 0.029 \\
\hline $\mathrm{SO}_{3}$ & 1.643 & $\mathrm{SrO}$ & 0.094 \\
\hline
\end{tabular}




\begin{tabular}{c|c|c|c}
\hline $\mathrm{K}_{2} \mathrm{O}$ & 1.421 & $\mathrm{SrO}$ & 5.212 \\
\hline $\mathrm{CaO}$ & 41.190 & Total & 100 \\
\hline
\end{tabular}

The granulometric composition of aggregates was performed under the parameters set by ASTM C33 [23] and particle-size distribution is presented in Table 3. The fine aggregate used in this study was of quartz origin and had maximum size of $0.6 \mathrm{~mm}$ and fineness modulus of 1.78 as its granulometric composition. Concerning physical indexes, specific gravity and unit weight of material were determined as ASTM C136 [24] stipulates and the results were $2.73 \mathrm{~g} / \mathrm{cm}^{3}$ and $1.45 \mathrm{~g} / \mathrm{cm}^{3}$, respectively. The natural coarse aggregate was of basalt origin and had specific gravity of $2.89 \mathrm{~g} / \mathrm{cm}^{3}$, as per tests set by ASTM C136 [24]. Its unit weight was $1.52 \mathrm{~g} / \mathrm{cm}^{3}$. The grogs were crafted from red ceramic structural bricks and were crushed in a jaw crusher, so the resulting residues measured up to $12.5 \mathrm{~mm}$. The values that were found for maximum size of aggregate and fineness modulus were $12.5 \mathrm{~mm}$ and 5.91, respectively, and the granulometric composition of the material followed ASTM C33 [23]. Specific gravity and unit weight were determined as per ASTM C136 [24] and resulted in $2.72 \mathrm{~g} / \mathrm{cm}^{3}$ and $0.9 \mathrm{~g} / \mathrm{cm}^{3}$, respectively. The total water absorption of this aggregate was determined through the method used by Werle [21] and turned out to be $17.88 \%$ within the 120 initial minutes and $20.65 \%$ in 24 hours. The water absorption of the sand was $7.97 \%$ and the gravel of $2.3 \%$, showing the great difference of absorption of the recycled aggregate to the natural aggregate.

Table 3: Particle-size distribution of aggregates

\begin{tabular}{|c|c|c|c|c|c|c|}
\hline \multirow{2}{*}{$\begin{array}{c}\text { MESH } \\
\text { OPE- } \\
\text { NING } \\
(\mathbf{m m}) \\
\end{array}$} & \multicolumn{2}{|c|}{ FINE AGGREGATE } & \multicolumn{2}{|c|}{$\begin{array}{l}\text { NATURAL COARSE AGGRE- } \\
\text { GATE }\end{array}$} & \multicolumn{2}{|c|}{$\mathrm{CCW}$} \\
\hline & $\begin{array}{l}\text { RETAI- } \\
\text { NED \% } \\
\end{array}$ & $\begin{array}{c}\text { CUMULATI- } \\
\text { VE \% } \\
\end{array}$ & $\begin{array}{l}\text { RETAI- } \\
\text { NED \% } \\
\end{array}$ & $\begin{array}{c}\text { CUMULATI- } \\
\text { VE \% } \\
\end{array}$ & $\begin{array}{l}\text { RETAI- } \\
\text { NED \% }\end{array}$ & $\begin{array}{c}\text { CUMULATI- } \\
\text { VE \% } \\
\end{array}$ \\
\hline 12.5 & 0 & 0 & 0.2 & 0.2 & 31.1 & 31.1 \\
\hline 9.5 & 0 & 0 & 8.3 & 8.5 & 19.1 & 50.2 \\
\hline 6.3 & 0 & 0 & 32.5 & 41.0 & 18.8 & 69.0 \\
\hline 4.8 & 0 & 0 & 27.3 & 68.4 & 7.8 & 76.8 \\
\hline 2.4 & 0 & 0 & 25.8 & 94.1 & 8.5 & 85.3 \\
\hline 1.2 & 0 & 0 & 4.3 & 98.4 & 5.1 & 90.4 \\
\hline 0.6 & 1.0 & 1.0 & 1.2 & 99.6 & 2.8 & 93.2 \\
\hline 0.3 & 76.6 & 77.6 & 0.2 & 99.8 & 3.1 & 96.3 \\
\hline 0.15 & 21.6 & 99.2 & 0.1 & 100 & 2.0 & 98.3 \\
\hline 0.075 & 0.8 & 100 & 0 & 100 & 1.4 & 100 \\
\hline $\begin{array}{l}\text { Bottom } \\
(<0.15)\end{array}$ & 0 & 100 & 0 & 100 & 0.3 & 100 \\
\hline $\begin{array}{l}\text { Fineness } \\
\text { modulus }\end{array}$ & \multicolumn{2}{|c|}{1.78} & \multicolumn{2}{|c|}{5.78} & \multicolumn{2}{|c|}{5.91} \\
\hline $\begin{array}{c}\text { Maximum } \\
\text { size }\end{array}$ & \multicolumn{2}{|c|}{$0.6 \mathrm{~mm}$} & \multicolumn{2}{|c|}{$12.5 \mathrm{~mm}$} & \multicolumn{2}{|c|}{$12.5 \mathrm{~mm}$} \\
\hline
\end{tabular}

\subsection{Dosage method}

The mixture was chosen from the satisfactory results of Gieseler and Tutikian [25] and the materials used have characteristics identical to those used in the work referenced. The proportion used for crafting the grout was 1: 2.2: 1.7 (cement: fine aggregate: coarse aggregate), in mass. Regarding the dry recycled coarse aggregate, the percentage of substitution with respect to natural was of $0,25 \%, 50 \%$ and $75 \%$, in volume. The initial slump of the structural grout's was fixing in $230 \mathrm{~mm}$. A HRWR based on polycarboxylates was used for grouts with $\mathrm{CCW}$, so that they would reach the same initial slump. 


\subsection{Mix, produce and curing the specimens}

A vertical axis concrete mixer was used for mixing the matrices. The mixing sequence followed this order: gravel, $1 / 3$ of water, cement, $1 / 3$ of water, natural fine aggregate, and the remaining water for the reference mixture. For mixtures with grogs, the materials were disposed in this order: natural coarse aggregate, $1 / 4$ of water, cement, $1 / 4$ of water, $\mathrm{CCW}, 1 / 4$ of water, natural fine aggregate, the remaining water and the HRWR based on polycarboxylates. The CCW was not added along with the gravel, as it absorbs water in vast amounts. For the composites, the procedure of mixing a conventional concrete was used, making slight adjustments so that there was enough water to hydrate the cement, since there is a great retention of water by the CCW.

The specimens of each mixture were molded in cylindrical forms of 100x200 mm, in accordance with ASTM C39 [26], whereas their compaction was performed manually with two layers of concrete that were rodded 12 times each. Then, the samples were demolded and were stored in a curing chamber with temperature of $21 \pm 2{ }^{\circ} \mathrm{C}$ and humidity of de $95 \pm 3 \%$. The specimens remained under these conditions until the test day. The procedures established by RILEM TC 116 [27] were followed when testing for total and capillary water absorptions.

\subsection{Slump test}

The methods for testing slump loss on concretes, as well as the apparatus needed for performing such tests, are determined by ASTM C143 [28]. The test begins as each mixture is mixed by assessing slump every 15 minutes until the total duration of 120 minutes is reached. The grouts were mixed again for 1 minutes and left to rest for 10 minutes between each verification. The weather conditions at the moment of the tests comprised temperature of $22^{\circ} \mathrm{C}$ and relative humidity of $83 \%$.

\subsection{Compressive strength and Elastic modulus}

Following ASTM C39 [26], a hydraulic press with capacity of $2000 \mathrm{kN}$ was used. Load was applied at a rate of $0.25 \pm 0.05 \mathrm{MPa} / \mathrm{s}$ until failure. The elastic modulus test was performed on the same equipment, following the ASTM C469 [29] method. The compressive strength and elastic modulus tests were performed at 28 days, considering that 12 specimens per grout.

The superficial treatment of the specimens was performed with grinding machine, ensuring the flatness of the faces for the compressive strength tests and elastic modulus.

\subsection{Capillary water absorption}

The capillary water absorption test followed RILEM TC 116 [27]. Samples of 100x50 mm were used, totalizing three samples per mixture. These were stored in an oven at $105 \pm 5^{\circ} \mathrm{C}$ for $24 \mathrm{~h}$. The specimens had their lateral and top surfaces sealed, remaining with the bottom surface exposed to a water blade of $3 \mathrm{~mm}$. Measurements of mass were performed at 30 seconds, 1, 2, 3, 4, 5 and 10 minutes, 1, 2, 4, 8 and 24 hours. The excess of water was removed from the contacting surface before each weighing.

\subsection{Total water absorption, void ratio and specific gravity}

The tests of total water absorption, void ratio and specific gravity were performed in accordance with ASTM C642 [30], so three samples of 100x200 mm were used per mixture. The samples were stored in an over at $105^{\circ} \mathrm{C} \pm 5^{\circ} \mathrm{C}$ for 72 hours, and then were submerged in water with temperature of $23^{\circ} \mathrm{C} \pm 2^{\circ} \mathrm{C}$ for 3 days. Afterwards, they were submerged in boiling water for 5 hours.

\section{RESULTS AND DISCUSSION}

\subsection{Slump test}

The slump test results are presented in Table 4 and Figure 1 considering an initial slump of $230 \mathrm{~mm}$. 
Table 4: Slump loss results

\begin{tabular}{|c|c|c|c|c|c|c|c|c|c|c|}
\hline \multirow{2}{*}{ MIXTURE } & \multicolumn{10}{|c|}{ SLUMP LOSS (mm) } \\
\hline & INITIAL & $\mathbf{0}$ min & 15 min & $30 \mathrm{~min}$ & $45 \mathrm{~min}$ & $60 \mathrm{~min}$ & $75 \mathrm{~min}$ & 90 min & 105 min & $120 \mathrm{~min}$ \\
\hline REF & \multirow{4}{*}{230} & 0 & 0 & 10 & 20 & 20 & 20 & 20 & 25 & 30 \\
\hline $\mathrm{CCW} 25 \%$ & & 0 & 15 & 20 & 20 & 25 & 30 & 55 & 85 & 150 \\
\hline $\mathrm{CCW} 50 \%$ & & 0 & 10 & 15 & 45 & 105 & 155 & 190 & 205 & 220 \\
\hline $\mathrm{CCW} 75 \%$ & & 0 & 95 & 145 & 195 & 210 & 210 & 220 & 225 & 230 \\
\hline
\end{tabular}

Fig. 1: Slump loss along 2 hours for the mixtures analyzed

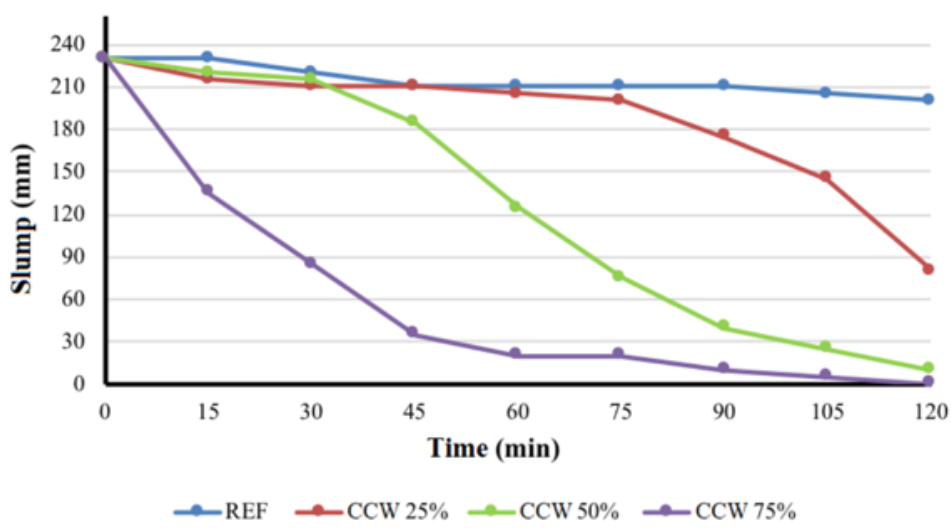

All matrices obtained similar behavior until the initial 30 minutes, with the exception of the CCW $75 \%$, which at the end of this period already showed a $63 \%$ slump loss in function of the others. Thus, the properties of the matrix were highly affected due to the inclusion of the high content of aggregate. At that moment, the HRWR started losing effect, as there was considerable decrease in moisture in the matrix. Analyzing the CCW matrix $75 \%$, the loss in the initial 15 minutes was $41 \%$. At 45 minutes the results were even more affected, reaching only $35 \mathrm{~mm}$ of slump, which represented a variation of $85 \%$ in relation to the initial value. Thus, the CCW $75 \%$ matrix was mostly affected by the addition of the ceramic aggregates. The CCW $50 \%$ mixture presented similar behavior to the CCW 75\%, but the slump loss was intensified after 45 minutes, period which there was a $20 \%$ lower slump reduction than the initial one. The variation of this mixture in the fresh state was verified until the 90 minutes, when presented slump reduction of $40 \mathrm{~mm}$.

The slump reduction in grouts with higher content of $\mathrm{CCW}$ is explained by the sharp absorption of water by these aggregates, since they soak about $18 \%$ of water in 45 minutes. Since there is water consumption of the cement paste, the matrix loses viscosity and the HRWR its function, so the drops were more accentuated. Thus, the internal moisture content in the matrix is relevant in maintaining consistency over 120 minutes. With the absorption of $18 \%$ moisture by the ceramic aggregate in $45 \mathrm{~min}$, the w/c ratio of the mixture is decreased. Thus, the property of the ceramic aggregate directly affects the consistency of the cementitious matrix and the higher its content of addition, the higher the water consumption. The amount of water per cubic meter in the CCW $75 \%$ matrix goes from 229 liters to 143 liters, that is, w/c ratio is equivalent to 0.38 .

The $25 \%$ REF and CCW mixtures obtained the similar behavior up to the 75 minutes. From this, the consistency of the mixture with ceramic aggregates was strongly altered, finishing the test with $80 \mathrm{~mm}$, that is, $65 \%$ reduction. The reference matrix did not present a considerable reduction of slump loss $(<15 \%)$ at the end of 120 minutes.

Thus, it is verified that the addition of the ceramic aggregate affects the consistency of the grates over time, where the $75 \%$ content presented the most severe losses. The mixture CCW $50 \%$ and CCW $75 \%$ obtained similar results at the end of the test, 10 and $0 \mathrm{~mm}$, respectively. The CCW $25 \%$ obtained the best results among all mixtures with ceramic aggregates. That demonstrated the difficulty of working with high amounts of grog in the fresh state, even with the use of HRWR. Under these circumstances, the reduced amount of free water in the paste impacted the effect of the admixture, considering that the admixture shows good performance on mixture with adequate moisture levels. 


\subsection{Compressive strength}

Figure 2 depicts the test values for compressive strength and standard deviation at 28 days, for a clearer view.

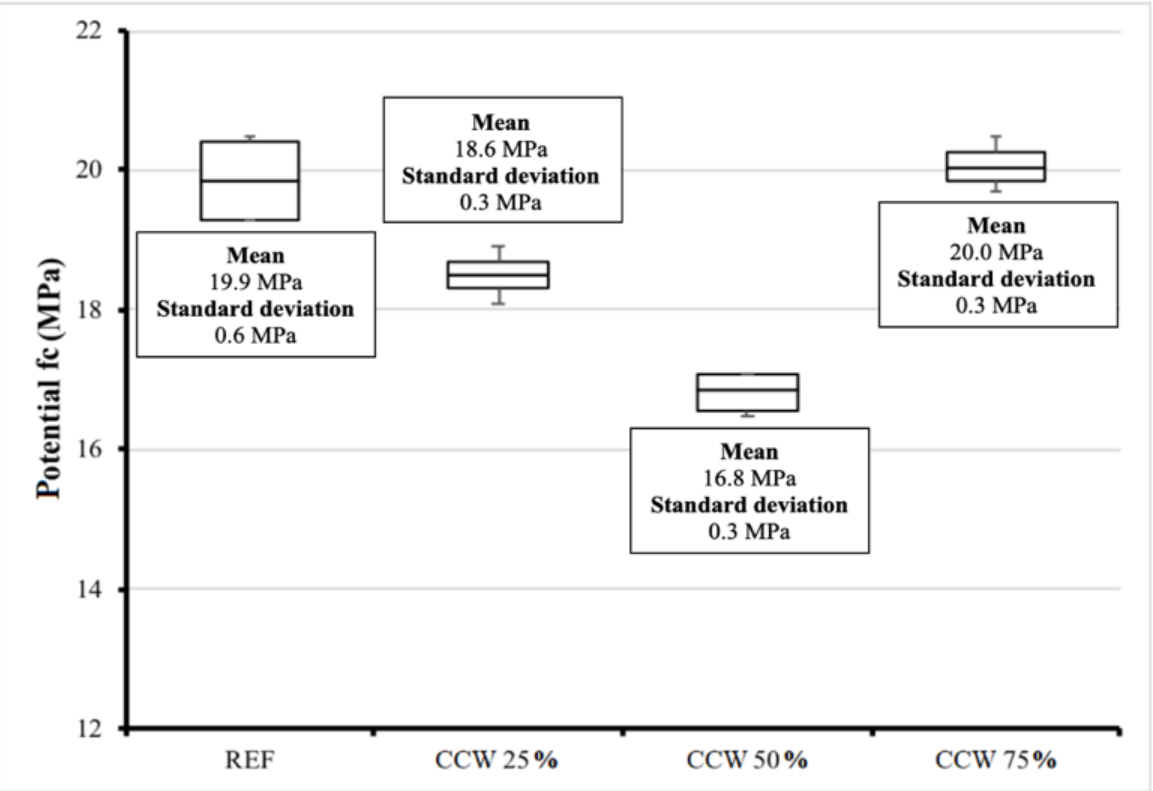

Figure 2: Compressive strength of matrices at 28 days.

Based on Figure 2, it is verified that the potential compressive strengths are higher than $15 \mathrm{MPa}$, as specified in the ABNT NBR 15961-2 [19]. In addition to these, it is important to note that the CCW 75\% mixture presented the highest resistance of this study, in comparison to the others, and can be classified as structural grout. The CCW $75 \%$ presented values similar to those of REF with average of 20.0 and $19.9 \mathrm{MPa}$, respectively. Thus, it can be stated that the mixture containing $75 \%$ of ceramic aggregates little affects the reference matrix in the compressive strength. The identified standard deviation was less than $1 \mathrm{MPa}$, presenting uniformity in the execution of the tests and production of another composites. It should be noted that the smallest standard deviations were identified in the specimen with $\mathrm{CCW}$.

The loss of strength for other samples due to the use of CCW was 1.3 MPa and 3.1 MPa for CCW $25 \%$ and CCW 50\%, respectively, in comparison with REF. Results showed that strength is reduced as the substitution amount increases, as happened to $\mathrm{CCW} 25 \%$ and $\mathrm{CCW} 50 \%$. The $\mathrm{CCW} 75 \%$ revealed a change of expectation, since the CCW were fragmented by the mixer because they were brittle and had low strength. Some solid grains became powdery during the mixing process, which contributed to the particles' degree of packing. In the case of CCW $75 \%$, the high amount of grogs made more grains fracture, which ended up having their sizes reduced, thus favoring packing of particles.

Another possible cause of strength gain identified in the $\mathrm{CCW} 75 \%$ matrix is related to the water consumption of the mixture. As the addition of ceramic aggregates was intensively increased, the amount of total water in the mixture was reduced by the consumption of the aggregates, with the lowest addition of water of the research per cubic meter, that is, 142 liters. Thus, the ceramic aggregate potentiated the reduction of the initial w/c ratio, which was 0.61 , to 0.38 . According to Mehta and Monteiro [31], the lower the w/c ratio, the better the cement matrix results in the hardened state. As for the CCW $25 \%$ and CCW $50 \%$ mixtures, the w/c ratio was slightly lower than the initial one, tending to a reduction in compressive strength.

Even if the reference matrix had the largest amount of water possible for hydration of the cement grains, its compressive resistance is related to the large aggregate (basaltic), which can provide high rigidity to the system when compared to the ceramic material, according to Ehrenbring et al. [32]. 


\subsection{Elastic modulus test}

The results for the elastic modulus test are depicted in Figure 3.

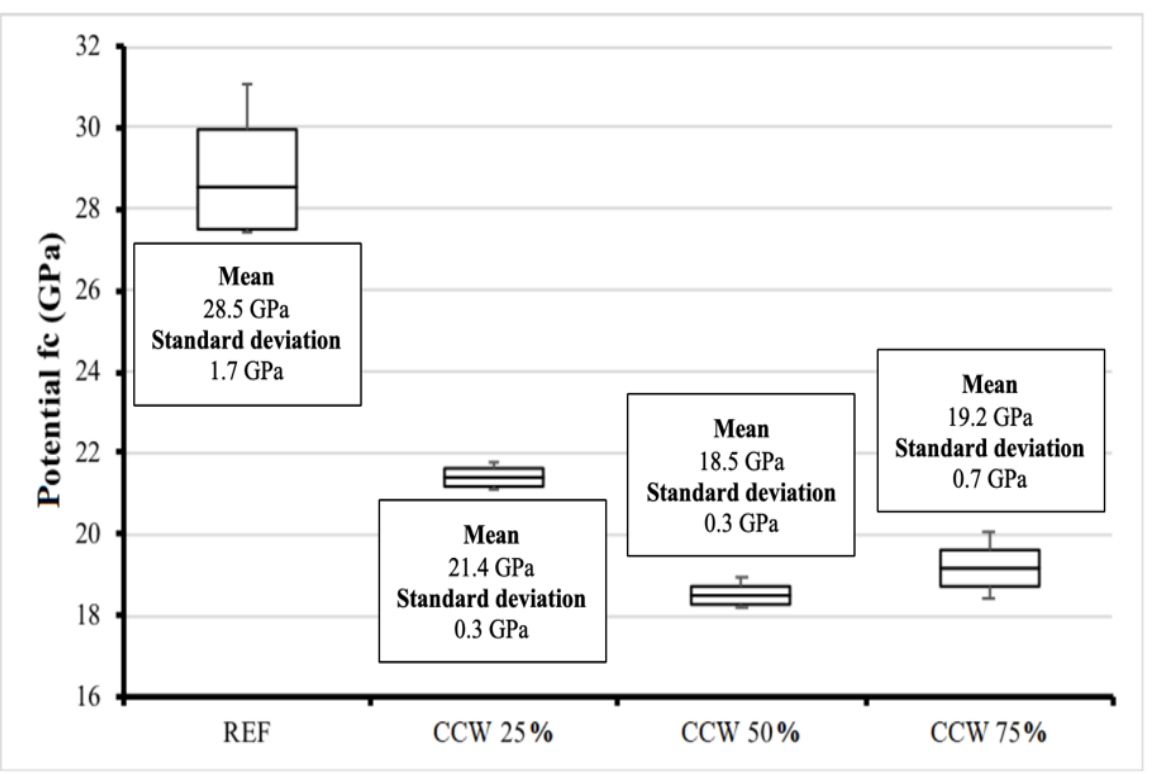

Figure 3: Elastic modulus of the mixtures at 28 days.

Mixture REF presented the best elastic modulus, meaning that it suffered less strain compared to the stress of others. The result of $28.9 \mathrm{GPa}$ was reached mainly due to the fact that the mixture did not have $\mathrm{CCW}$ added to it, which contain a considerable amount of voids that reduce toughness and the natural aggregate has high rigidity, since, in general, aggregates with smaller modulus of elasticity have concretes with their own resources as well. It was noted that changing this type of aggregate in fractions of 25 to $75 \%$ reduced the mixture's elastic modulus by up to $36 \%$. Comparing results between grouts with $\mathrm{CCW}$, the maximum standard deviation was $0.72 \mathrm{GPa}$. On the other hand, the reference mixture reached a variation of 1.74 $\mathrm{GPa}$, showing higher instability from sustaining higher heterogeneity.

The mixture that presented the smallest result for elastic modulus was CCW 50\%, whereas a comparison with CCW $75 \%$ showed that the results were close to each other, what can be explained by variations pertaining the elastic modulus test. Nevertheless, the mixture with $25 \%$ of substitution yielded the highest result for elastic modulus among grouts with $\mathrm{CCW}$, as it provided less internal voids and higher volume of natural aggregates., how to they explain Ehrenbring et al. [32].

\subsection{Total water absorption, void ratio and specific gravity tests}

The results for total water absorption and void ratio for the grouts of this study are illustrated in Figure 4. 


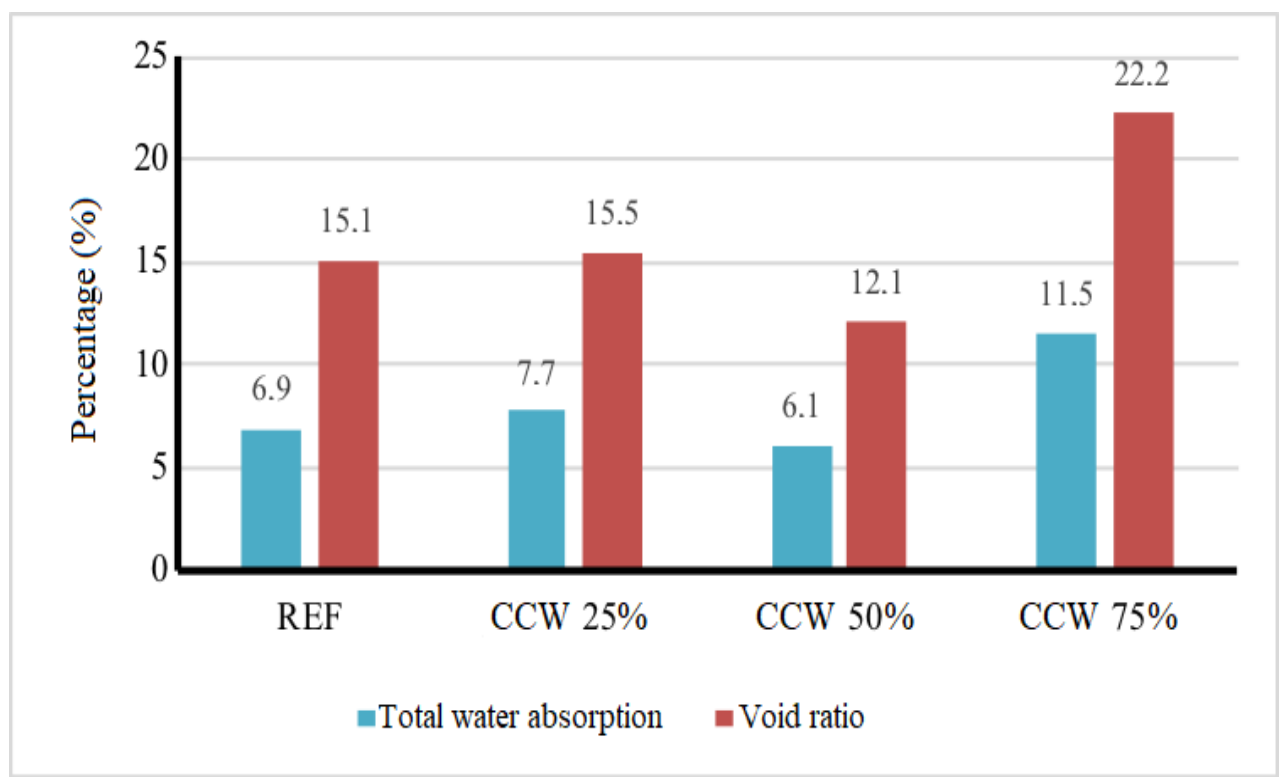

Figure 4: Total water absorption and void ratio of samples at 28 days.

It is noted that increasing the amount of ceramic aggregates causes negative impact to matrices with $\mathrm{CCW}$. The CCW $75 \%$ presented increase to its void ratio and total water absorption by $32 \%$ and $40 \%$ respectively, in comparison with REF. This increase is related to the physical formation of the aggregate, considering that $\mathrm{CCW}$ is more porous than gravel, therefore increasing the overall amount of voids in the composites.

CCW 25\% displayed results similar to the reference grout's due to low concentration of ceramic material when compared to the others. The reduction of the parameters of CCW $25 \%$ with respect to REF was $2.6 \%$ for void ratio and $10.4 \%$ for total water absorption, confirming the similarity.

The tests analyzed in this section suggest that $\mathrm{CCW} 50 \%$ has a behavior that tends to an optimal point, reaching $6.1 \%$ for total water absorption and $12.1 \%$ for void ratio, forasmuch as these results can be related to interactions between both aggregates that were used, natural and waste.

The specific gravity of the blend with $0 \%$ of ceramic waste reached the highest value, $2.20 \mathrm{~g} / \mathrm{cm} 3$. As the ceramic waste content was increased, the specific mass was decreased, being 2.02, 2.00 and $1.92 \mathrm{~g} / \mathrm{cm} 3$ for grouts with 25,50 and $75 \%$, respectively. Hence, as the amount of substitution of natural aggregate for $\mathrm{CCW}$ increases, the corresponding values for hardened state specific gravity decrease. Such behavior refers to the aggregate's specific gravity and void ratio, which affect the mixture directly.

\subsection{Capillary water absorption test}

The test results for capillary water absorption are pinpointed in Table 5 and Figure 5.

Table 5: Capillary water absorption values for the mixtures studied

\begin{tabular}{c|c|c|c|c|c|c|c|c|c|c|c|c|c}
\hline GROUT & $\mathbf{0 ~ s}$ & $\mathbf{3 0} \mathbf{~ s}$ & $\mathbf{1} \mathbf{~ m i n}$ & $\mathbf{2} \mathbf{~ m i n}$ & $\mathbf{3} \mathbf{~ m i n}$ & $\mathbf{4} \mathbf{~ m i n}$ & $\mathbf{5} \mathbf{~ m i n}$ & $\mathbf{1 0} \mathbf{~ m i n}$ & $\mathbf{1} \mathbf{h}$ & $\mathbf{2} \mathbf{~ h}$ & $\mathbf{4} \mathbf{h}$ & $\mathbf{8 ~ h}$ & $\mathbf{2 4} \mathbf{~ h}$ \\
\hline REF & 0 & 0.19 & 0.31 & 0.40 & 0.54 & 0.61 & 0.61 & 0.75 & 1.39 & 2.01 & 2.83 & 4.11 & 7.36 \\
\hline CCW 25\% & 0 & 0.05 & 0.20 & 0.20 & 0.24 & 0.30 & 0.31 & 0.50 & 1.40 & 2.38 & 3.07 & 4.39 & 7.51 \\
\hline CCW 50\% & 0 & 0.22 & 0.37 & 0.45 & 0.55 & 0.58 & 0.62 & 0.66 & 1.08 & 1.45 & 1.90 & 2.61 & 4.39 \\
\hline CCW 75\% & 0 & 0.02 & 0.07 & 0.14 & 0.18 & 0.21 & 0,25 & 0.40 & 1.04 & 1.59 & 1.92 & 2.45 & 3.57 \\
\hline
\end{tabular}




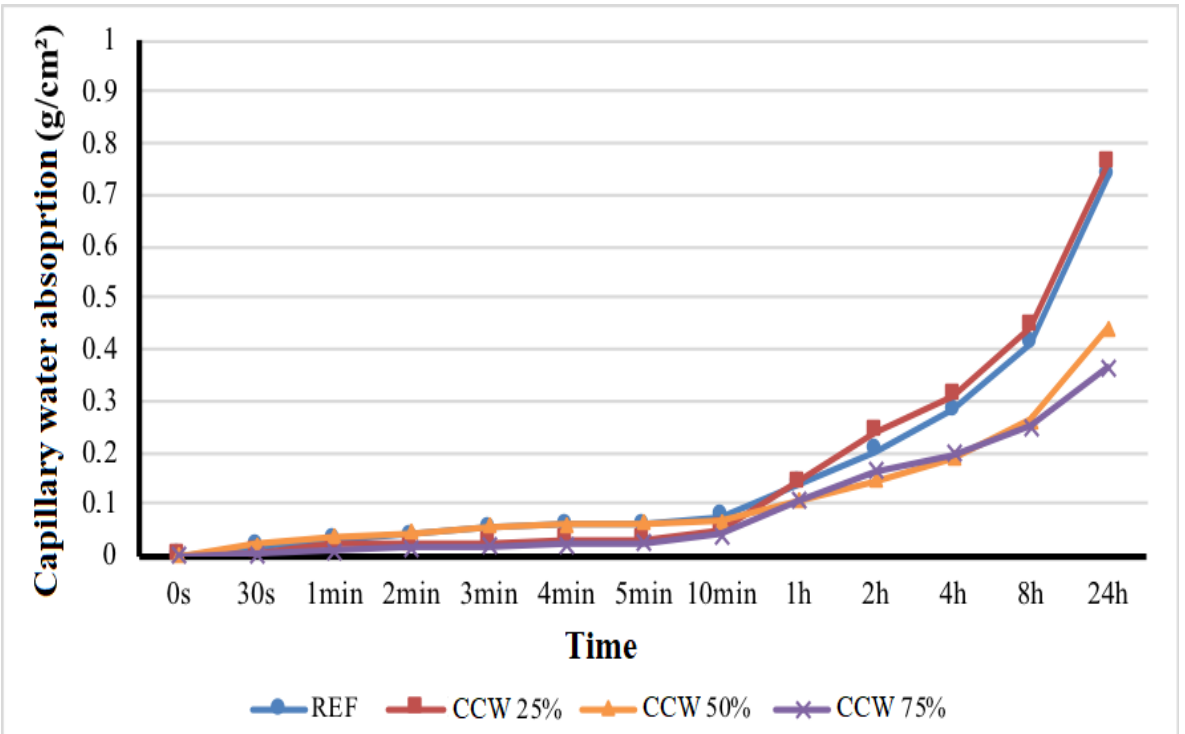

Figure 5: Capillary water absorption for grouts at 28 days.

It can be noted that none of the samples varied considerably. However, after 1 hour, the increase of water absorption became conspicuous for mixtures REF and CCW 25\%, mostly for the one with grog, which presented the highest water absorption, reaching $0.75 \mathrm{~g} / \mathrm{cm}^{2}$. The smallest values after the initial test period were yielded by grouts CCW $50 \%$ and CCW $75 \%$.

After 4 hours of testing, the values for mixtures CCW 50\% and CCW 75\% dissociated from other mixtures by $50 \%$. After 24 hours, the samples with higher amounts of grog presented average capillary water absorption $47 \%$ smaller.

The comparison of these results with total water absorption and void index show that CCW $75 \%$ yielded the smallest capillary water absorption, in spite of achieving the highest percentage of voids and the smallest total water absorption and to the heavy matrix due to the low w/c in the CCW 50\% and CCW $75 \%$. This fact is related to increase of pore diameter, which hinder upward penetration of water molecules, saturating only a slight layer of the sample. The same happened to CCW $50 \%$, which also turned out to be influenced by diameter of pores. Therefore, it can be stated that, the larger the diameter of the pore, the less water will be absorbed due to the reduction of stress caused by water surface tension. In the submersion, the high absorption of the CCW commands the test and therefore, the values are water absorption are higher.

\section{CONCLUSIONS}

The experimental procedure led to the following conclusions:

- The compressive strength and elastic modulus of samples with CCW were impaired, despite every mixture presenting results that were satisfactory with regards to compressive strength, with results close to each other at 28 days and above the limits of ABNT NBR 15961-2 [19];

- The smallest slump losses were yielded by CCW 25\%, which turned out to be similar to REF up to 90 minutes of testing. On the other hand, the composites with higher CCW amounts displayed high losses after 30 minutes;

- The specific gravity of grouts with recycled aggregate was smaller than that of REF, as expected, since part of the natural aggregate that had higher specific gravity was substituted for a lighter aggregate;

- The capillary water absorption of mixtures with waste was lower than the reference mixture, except for $\mathrm{CCW} 25 \%$, which can be related to pores of shorter diameter. Thus, mixtures with substitution amounts of 50 and $75 \%$ may present higher durability, as the absorption remained below 0.45 $\mathrm{g} / \mathrm{cm}^{2}$, preventing aggressive agents from entering the system.

Lastly, substituting natural coarse aggregate for CCW led to positive results, as CCW $25 \%$ was the most noteworthy mixture. Its results remained similar to the reference mixture throughout most of the experiment, indicating that it is possible to reuse waste generated in construction processes, even for higher substitution amounts occasionally. 


\section{BIBLIOGRAPHY}

[1] SANTOS, M. F. N., BATTISTELLE, R. A. G., HORI, C. Y., et al., "Importance of life cycle assessment in product analysis: possible applications in civil construction", Gepros - production, operations and systems management. Vol. 2, São Paulo, Brasil, pp.1-57, 2011.

[2] ŠIPOŠ, T. K., MILIC`EVIC, I., SIDDIQUE, R. "Model for mix design of brick aggregate concrete basedon neural network modelling", Construction and building materials, v.148, pp.757-769, 2017.

[3] GUO, H., SHI, C., GUAN, X., et al., "Durability of recycled aggregate concrete - a review", Cement and concrete composites, v.89, pp. 251-259, 2018.

[4] JOHN, V. M., AGOPYAN, V., "Recycling of construction waste", In: Seminar recycling of domestic solid waste. São Paulo, Brazil, 1-13, 2000.

[5] Brazilian association of companies of public cleaning and special waste (Abrelpe). Solid waste: a manual of good practices in planning, São Paulo Brazil, 2016.

[6] SCHACKOW, A., STRINGARI, D., SENFF, L., et al., "Influence of fired clay brick waste additions on the durability of mortars", Cement and concrete composites, v.62, pp. 82-89, 2015.

[7] BOSQUE, I. F. S., ZHU, W., HOWIND, T., et al., "Propertiesof interfacial transition zones (itzs) in concrete containing recycled mixed aggregate", Cementand concrete composites, v.81, pp. 25-34, 2017.

[8] TÜFEKÇI, M. M., ÇAKIR, Ö., "An investigation on mechanical and physical properties of recycled coarse aggregate (RCA) concrete with GGBFS", International journal of civil engineering, v.15, n. 4, pp 549-563, 2015.

[9] CABRAL, A. E. B., SCHALCH, V., AL MOLIN, D. C.C., et al., "Mechanical properties modeling of recycled aggregate concrete", Construction building materials, pp. 421-430, 2010.

[10] GONZÁLEZ, J. S., GAYARRE, F. L., PÉREZ, C. L. C., et al., "Influence of recycled brick aggregates on properties of structural concrete for manufacturing precast prestressed beams", Construction and building materials, v.149, pp.507-514, 2017.

[11] OMARY, S., GHORBEL, E., WARDEH, G., et al., "Mix design and recycled aggregates effects on the concrete's properties", International journal of civil engineering, pp.1-20, 2017.

[12] MARTINS, F. A. "Critical analysis of the use of a rationalized system: the case of structural masonry in concrete blocks in residential buildings", In: Technological research institute of the state of São Paulo, São Paulo, Brazil, 2001.

[13] KHALAF, F. M. "Properties of new and recycled clay brick aggregates for use in concrete", Journal of materials in civil engineering, v.17, pp. 456-464, 2005.

[14] SUZUKI, M., MEDDAH, R., SATO, R. "The use of coarse and fine crushed bricks as aggregate in concrete", Construction and building materials, v. 22, pp. 886-893, 2008.

[15] ADAMSON, M., RAZMIJOO, A., POURSAEE, A. "Purability of concrete incorporating crushed brick as coarse aggregate", Construction and building materials, v. 94, pp. 426-432, 2015.

[16] Brazilian association of technical standards NBR 12118: Single concrete masonry concrete blocks - Test methods. Rio de Janeiro, Brazil, 1-14, 2013.

[17] GOUVEIA, P. S. "Formulation of light gratings for the cementation of onshore oil wells", In: Digital repository of the Federal University of Rio Grande do Norte. Natal, Brazil, pp. 1-74, 2011.

[18] WADA, P. H. "Study of the incorporation of red ceramic waste in the concrete composition for use in molded stakes in loco", In: Digital repository of Universidade Estadual Paulista, São paulo, Brazil, pp.1-109, 2010.

[19] Brazilian association of technical standards. NBR 15961-2: Structural masonry - concrete blocks. Part 2: Execution and control of works. Rio de Janeiro, Brazil, 1-35, 2011.

[20] HAMID, R. G., PARSEKIAN, A. A., DRYSDALE, G. "Behavior and desing of structural masonry", Edufscar, São Paulo, Brazil, 1-625, 2012.

[21] WERLE, A. P. "Analysis of methodologies used to characterize the water absorption of recycled concrete as an aggregate", In: encontro nacional de tecnologia do ambiente construído. Porto Alegre, Brazil, 1$11,2011$.

[22] ASTM (2018). C150: Standard specification for Portland cement. West Conshohocken, USA, 1-9.

[23] ASTM (2018). C33: Standard specification for concrete aggregates. West Conshohocken, USA, 1-8. 
[24] ASTM (2014). C136: Standard test method for sieve analysis of fine and coarse aggregates. West conshohocken, USA, 1-5.

[25] GIESELER, S., TUTIKIAN, B. "Study of grates produced with recycled aggregate of ceramic block residue incorporating hydrated lime contents", Ambiente construído, v. 13, n. 3. Porto Alegre, Brazil, pp. 303-315, 2013.

[26] ASTM (2018). C39: Standard test method for compressive strength of cylindrical concrete specimens. West conshohocken, USA, 1-8.

[27] RILEM (1999) TC 116 - PCD: Permeability of concrete as a criterion of its durability. Materials and structures, 32, 1-6.

[28] ASTM (2015). C143: Standard test method for slump of hydraulic-cement concrete. West Conshohocken, USA, 1-4.

[29] ASTM (2014). C469: Standard test method for static modulus of elasticity and poisson's ratio of concrete in compression. West Conshohocken, USA, 1-5.

[30] ASTM (2013). C642: Standard test method for density, absorption, and voids in hardened concrete. West conshohocken, USA, 1-3.

[31] MEHTA, P. K.., MONTEIRO, P. J., Concreto: microestrutura, propriedades e materiais, 1. ed., São Paulo, Pini, 2014.

[32] EHRENBRING, H. Z., TUTIKIAN, B. F., REIS, D. M., "Grout for structural masonry: study for the use of ceramic residue mixing", Revista Matéria, v.2, n. 3, Rio de Janeiro, 2017.

ORCID

Hinoel Zamis Ehrenbring

Maira Janaina Ott

Bianca Carlin Cadore

Diego Logue do Espirito Santo

Bernardo Fonseca Tutikian https://orcid.org/0000-0002-0339-9825

https://orcid.org/0000-0001-8450-5855

https://orcid.org/0000-0002-1611-1173

https://orcid.org/0000-0003-3315-4412

https://orcid.org/0000-0003-1319-0547 